\title{
Online Film Platforms and the Future of the Cinema
}

\author{
Ormanlı 0.1 \\ ${ }^{1}$ Okan ORMANLI, İstanbul Aydın University, (Turkey) \\ e-mail: okanormanli@aydin.edu.tr
}

\begin{abstract}
Today technology has dominated almost all facets of the life and being no longer a luxury, it has become an ordinary component of everyday life. In addition to indispensable functions in such fields as healthcare, industry and education, it is becoming more and more important in arts and entertainment. While art branches are transforming and preserving their essence, they should be open to innovations. Technologic screens are now being used in theatre plays, museums and exhibitions and movies can simultaneously be broadcasted alive in cinema halls at different countries of the world. Cinema halls are no longer places where only movies are shown. Having a past dating back to over 120 years, the works of the art of the cinema were watched on the silver, television, computer and mobile phone screens respectively. As television and then video cassette, DVD, pay TV, digital movie and online series streaming platforms became sophisticated, it revealed that there should be some kind of screening calendar among all. This can vary from country to country and sometimes it can be subject to written rules. Today video cassettes almost completely disappeared and DVDs are not as popular as they used to be. For this reason, today mediums of movie screening apart from the cinema are classical television channels, digital platforms, IPTVs and online streaming movie and series platforms. The greatest competition takes place when the time, conditions and place of the first run of high quality and popular movies and series are concerned. As the number of competitors increase, income and profit pie shrink, traditional approaches and rules wear off, change and sometimes disappear. The main purpose of this study is to argue Netflix, a US-originated entity having emerged in this competitive environment and gained worldwide popularity, its position at both television and cinema industry, its current and future implications. While Netflix, founded in 1997, was previously a company selling and renting video cassettes and DVDs turned out to be a movie and series giant having 130 million subscribers in 190 countries today. Providing viewers with special individual displays and recording theirs likes and preferences in numbers, Netflix produces and presents their own original movies and series to its subscribers. Sending film to Cannes Film Festival in 2017, simultaneous distribution of the movie "Roma" in both its own platform and at cinemas, its success at Emmy awards and its participation in Oscar awards are the outcomes of Netflix's efforts of prestige and leadership in global television and film industry. These achievements and goals are deemed aggressive and dangerous by some cinema and television milieus and it is claimed that they will hurt the cinema and cinema halls. In this qualitative study, starting from the tension between Netflix and festival management at Cannes Film Festival in 2017, the future of the cinema through success / failure of Netflix at last Oscar ceremony will be analyzed.
\end{abstract}

Keywords: Digitalization, Online, Netflix, Cannes Film Festival.

\section{Introduction}

Initially, technology was mostly one of the key subjects of future insights, science-fiction literature and movies and studies related to the space. After Industrial Revolution, age of communication and age of computer, today such phenomena as Industry 4.0 and Web 3.0 as well as $5 \mathrm{G}$ technologies are being mentioned and discussed. Computer and internet infrastructure, software and hardware quickly develop and get stronger thanks to technology. Digital devices and mediums are no longer relatively expensive or inaccessible and getting more prevalent. From time to time, various scientific and industry-specific studies in this field share statistical data with the public. According to these data, now a lot of people are connecting to the internet through computers or mobile phones in an online way (Şakiroğlu-Akyol, 2018). While some of the internet activities are mailing, playing games 
and reading news, the majority of internet users are spending time at social media and watch series or movies.

The number of subscribers to digital platforms which are mostly paid are gradually increasing both in Turkey and abroad. Subscribers can watch the movies, series and similar contents they wish regardless of time and place. Studies conducted in the field emphasize that ways of watching and viewer habits are changing. Movies or series are now being watched on mobile phones and computers rather than traditional televisions. Moreover, people binge-watch the seasons of series in a couple of days. In this context, some series are being shot with big budgets, episode numbers are kept in minimum and new seasons are being released later. These kinds of approaches also reflect to the quality of series. Series produced by the various film companies can be broadcasted in a lot of countries and can reach millions of people. While the most known digital platforms having the highest number of subscribers abroad are Netflix, Amazon Prime and Hulu etc., TV+, Blu TV, Puhu TV and Tivibu are the first examples that come to mind in Turkey.

Netflix, the leading and pioneering digital platform in its area, will be predominantly focused and analyzed in this study. Founded as a DVD renting company during 1990s in the USA, Netflix is now a digital platform presenting hundred-thousand hours of series and movie content to near 130 million subscribers in 190 countries. The platform which is using the $20 \%$ of world's internet traffic has recently more focused on producing their own series and movies. It is also supporting local series and films in some countries at Europe. In 2017 Netflix attended Cannes Film Festival with two movies and withdrew from the festival when the festival committee mandated these two movies to be shown at cinema halls in France because the movies shown in France can't be shown online and in digital platforms until 36 months after their cinematic release. Netflix, having considered that it would incur commercial loss, withdrew these movies from the festival. Although two years passed over the tension in 2017, debates are still going on. When the old and traditional one confronts to the new and groundbreaking, the future of cinema has been included among the mostly debated issues. After Cannes Film Festival, the position of Netflix in Oscar Awards was started to be discussed before the Oscar ceremony and went on until the award ceremony. In this study, the present and near-future impacts of technology and being online on cinema will be argued by reviewing the related studies and opinions published in written, digital, daily, weekly or monthly periods within the last 2 years.

\section{Literature}

In May 2017, Cannes Film Festival witnessed a big crisis between online entertainment platform Netflix and festival committee about whether Netflix movies could be shown in France without being shown in French movie theatres. Debates are still going on in spite of 2 years passed. This crisis frequently brought up in written or electronical mediums at various places on the world. The crisis in 2017 was in fact the struggle between the old and the new, the traditional (analogue) and the future (digital). Viewing culture and viewer habits subject to change and transformation from time to time depending on the technological advances.

In this study, actual cinema and television magazines and internet sources was mostly benefited in line with the technological advances and the speed of digitalization. Written sources were also taken into consideration as a reference point. Besides resources in Turkish, resources in English and German were also benefited. One of the names making researches on viewer habits is Francesco Casetti. Professor Casetti is teaching lessons in cinema and media at Yale University. In his book titled as "The Lumiere Galaxy- 7 Keys Words for the Cinema to Come", he provides insights on the present and future of the cinema. Casetti's opinions will be referred in this study as well.

\section{Research}

Viewing pleasure and culture have become one of the integral parts of almost all societies for thousands of years. Billions of eyes have witnessed art on cave walls, theatre, opera and ballet stages, silver screen and television screens. At the end of 19th century and the beginning 20th century, various technological and artistic developments took place. In 1895, for the first time in history, commercial screening of a movie was made in France. The phenomenon of radio emerged in 1920 s and quickly spread to the world. In many developed Western societies, television broadcasts started in later 1930s and earlier 1940s. In this way, the television living its golden age in the USA in 1940 s and 1950s started to be active in many countries of the world as of 1960s. Each newly emerged technology was considered as a potential competitor to the previous one. In this context, cinema was 
considered as a competitor for both radio and television. At that time, some circles claimed that the end of the cinema arrived and it could not resist especially against the television. However, the art of the cinema resisted against its competitors and could survive till today by using the advantages of three-dimension, color and audio.

Starting to become popular in 1990s and be used by the billions of people today, internet is recently shown as one of the biggest competitors of the cinema. Before mobile phones became popular, people started to watch series and movies on desktop PCs and then notebooks. Through strengthening of internet infrastructure and especially increasing of mobile phone production and sales, millions of people watch series and movies on their mobile phones. By this way, people obtained the freedom of watching series and movies in a mobile way as much as they want wherever and whenever they want. This is the most important point which is focused in this study and thought about by the researchers working in this field. Subsequent to these advances, will people give up to go to the cinema? Departing from the sources mentioned in the literature part and the crisis specific to Netflix, an important online series and movie platform, in 2017 at Cannes Film Festival, the future of the cinema and cinema halls will be argued in this article.

Franseco Casetti, American movie theorist teaching and writing books about the issues and subjects referred in this study, published a book titled as "The Lumiere Galaxy - 7 Key Words for the Cinema to Come" in 2015. Casetti emphasizes the position and importance of the viewer in the future of the art of the cinema. Casetti gives places 7 key words in 7 parts of his book.

In the first key word which is "relocation", he refers to the transition of watching cinema films from cinema halls to other devices (mobile phones, computers etc.), namely, changing mediums. The second key word, which is "relic / icon", similar to the first one, focuses on the cinematic experiences apart from the cinema halls. Films are broken into pieces, which means they are watched in pieces at different places, and they almost become historical relics. For example, they revive in the living room of the home. Despite being copies, they revive again and become icons. In this context, we can talk about a substitute bringing the model to the life again. Replacing cinema turns into a relic or icon and achieves to preserve its authenticity in both ways.

Casetti describes the third key word, which is "assembly-montage", as written visual posts of the viewers on the movie in various watching platforms. The other key word, which is "expansion" refers to broadcasting, discussing and consumption of movies in multimedia as DVDs, computers, websites, trailers, comments. The other two key words, "hypertopia" and "display", have similar meanings. "Hypertopia" which does not have an exact Turkish equivalent means analyzing the substitution of traditional screen by alternative screens, walls and installations in museums. "Display" is described as the places and screens where cinema films lose meaning. In this context, the screens of new devices turn into an area of exposure. Many images flow and go, cease for a second and expose themselves to the users.

Seventh and the last key word is "performance". According to Casetti, when cinema is transferred to new devices, images become more inconsistent. The narrative part diminishes and becomes open to different meanings. The viewer profile is gradually changing as well. Now viewers are intertwined with not only one film but with many films. For this reason, they cannot be focused and lose concentration. The viewers cannot immerse themselves in movies and they only wander on the surface. In short, they cannot stick to the enclosed space and they become more interested in the realities of the potential world rather than those of the real one. As in the contemporary art, the viewer becomes more active and watching movie turns into a performance (Casetti, 2015:8-13).

In addition to Casetti, another scholar states the following: "In addition to all points touched in this study related to the cinema-viewing culture and the changing position of the viewer, what should not be forgotten is that cinema is an area of art rather than a technology and viewing experiences will not go beyond a technologic experience unless they do not include the distinctive practices of this art" (Taş Öz, 2012: 72).

Short history of Netflix and various articles and opinions on the company within last 2 years after Cannes Film Festival will be covered in this part of the study. For sure, in a study on how technological advances will affect and change cinema, Netflix is not the only actor, but one of the most important actors. As company grows, it gets more attention and reaction. In the context of limitations and flow of the study, only some of the reviewed and researched articles and opinions are selected. Selected articles and quotations are tried to be connected with Casetti's opinions and 7 key words. 
Netflix was founded by Reed Hastings in 1997 in the USA and shortly it turned into a 100billion-dolar company. It started first as a DVD sale and rental system. It initiated online sales and renting initiatives in 2000s. It started to match the content and the customer via an algorithm called "Cinematch". Viewer preferences and habits were categorized and filtered. Preferences of cinephiles provided new ideas to Netflix and thus, viewer interest emerged against the "70s cinema. In mid2000 s, $60 \%$ of the orders were placed as per the algorithm program called "Cinematch". Thanks to internet facilities and Netflix's effective strategies, Netflix made up $25 \%$ of internet data usage of North America in 2013 (Rolf, 2017:8).

After the tension and debate between Netflix and the festival committee of Cannes Film Festival in 2017, both parties made statements to several media organs. In this context, Ted Sarandos, one of the prominent executives of the company, gained a position as the spokesperson of Netflix. One of his statements, Sarandos stated that they had 50 movies in the making process across the world, besides 65 documentaries, they supported series productions in 19 countries in local languages. In this context, he expressed that they took the risk of production, but the studies in Hollywood were gradually taking less risk. He also said that they had spent 1,75 billion dollars to production and licensing of European movies since 2012. He added that more than half of the people watching these contents were non-Europeans and thus they were the biggest exporter of European content. According to Sarandos, only criteria which Netflix considered when producing the project is the personal ratings received by the viewers. In each movie, there are options of "like" and "dislike" on the screen. As per these options, the service decides on the next projects. Related to habits of going to cinema and tendency of watching movies out of cinema halls, Sarandos states that in the past he binge-watched 3 movies, but now the pleasure and environment of watching movie in the cinema hall has changed. Sarandos says now people look at their mobile phones and chat in cinema halls when the movie starts and even, they bring their dogs to cinema halls. For this reason, according to him, Netflix is not a competitor to be worried about losing viewer. He points that studio and cinema hall owners have their own home cinema systems. "Cinema lovers go to the cinema because they love films. Netflix cannot stop the ones who want to go to the cinema on Friday evenings. If you want to stay at home, even the most spectacular movie cannot get you out of home" says Sarandos (Colin, 2017).

In fact, what Sarandos points is that film production and the produced film reach to the viewers even in different mediums. For him, cinema love and viewing pleasure form the common ground. In this context, relocation, one of Casetti's 7 keywords, which means the changed viewing medium coincides with Netflix and similar platforms.

In an article titled as "Netflix isn't Killing Movies, Hollywood Studios and Theatres Are" by Jordan Zakarin", there are opinions on advantages or positive-negative aspects of Netflix and Amazon. While Amazon is supporting independent cinema, it also arises the question of how realistic to expect Amazon to embrace the art considering it is place where everything is sold and marketed apart from the cinema. There are also several opinions as "Netflix has so many films that it is like a person hoarding them, it hides the viewing rates of the movies and it embeds its best movies in its menus." In the article, it is also stated that important independent studio movies enter into pay and watch system when they could not find studio or internet showing support, so it is hard to blame Netflix and Amazon. Zakarin also claims that Hollywood studios which approaches only to profit-making movies rather than the innovative and risky productions are the real actors hurting the cinema. Additionally, he also points that expensive cinema tickets especially in USA put the viewers in a difficult situation (Zakarin, 2017).

After Cannes Film Festival in May 2017, many articles related to the subject were published in several cinema magazines in Turkey as well. In a cinema magazine named "Hayalperdesi", questions about the impacts of YouTube and Netflix on cinema were asked to some actors in the cinema industry. The article emphasizes the emergence of a new viewer generation which finds film festivals boring, rarely goes to the cinema, but strictly follows the movies and series. The number of viewers who are much more interested in and interactively related to the series are getting increased. Investors like Amazon shoots pilot episodes and leaves the decision to the viewers. The habit of watching movie or film online attracts the investors to this area. In this context, there is potential viewer which cannot be reached via television and cinema thanks to much more independent production (Yeni Mecra, 2017:43).

Above mentioned concepts and opinions remind the key words of Casetti, which are "expansion" and "display". Now, YouTube and similar mediums are the places where films are 
broadcasted, discussed and consumed at such multimedia environments as DVD, computer and websites. That kind of an expansion can be described as a "positive" development. However, when we take display on a background where the screens of new devices turn into an area of exposure and many images flow and go, the risk of content deprecation emerges in time, which can be deemed as a negative development.

Viewing habits data published by Netflix in 2017 support Casetti's views and insights. According to data, when subscribers themselves can decide what and when to watch, Netflix watching peaks at $5 \mathrm{AM}$ and $10 \mathrm{PM}$. In short, stereotyped TV realities in traditional TV channels become reversed. It is also globally claimed that TV watching rules are being rewritten. Commenting on research results of changed TV viewing habits, Cindy Holland, Vice-President of Original Content at Netflix says, "Within last 4 years when the consumers spend without being obliged to plan their day as per the streams of classical TV channels, TV watching habits changed drastically across the world. As Netflix, we delivered consumers the control of what to watch at all hours of the day and we observed how TV watching routines changed when they were provided with the freedom of going out of a fixed stream. This change is observed in millions of viewers across the world" (Netflix, 2017).

When Cannes-Netflix debates were new, an article titled as "Is this the end of cinema halls?" by Jak Şalom (one of the important names of Sinematek founded in 1965 in istanbul and made important contributions to cinema culture) was published in Altyazı magazine. In the article referring to the worldwide success of Netflix, states that there are 60 million subscribers of Amazon, the biggest competitor of Netflix. The article also covers the point of new rules imposed in Cannes due to Netflix movies, reminds the statements of Ted Sarandos about the lack of any obligation in Netflix to show movies at theatres. According to Sarandos, showtimes restrict viewers and sometimes some viewers disturb others. In this context, what matters is to watch movie regardless of the medium. Jak Şalom, one of the most important names of fist Sinematek founded in Turkey in 1965, regards Netflix and similar platforms as a threat to movie theatres. According to Şalom, film libraries, museums and clubs should assume an important mission. In this context, it is required to create art movie network. In this way, cinema halls can show both examples of mainstream and independent cinema (Şalom, 2017:8587).

At the begining of 2019, Sıla Şahingöz talks about a new development on the conflict between Netflix and Cannes. After this tensed process, the movies of "22 July" and "Roma" premiered in Venice Film Festival. Especially "Rome" attracted the attentions by winning the Golden Bear Award of the festival. However, all the positive criticism "Rome" has received all year long, its return home with an award from the Golden Globe and being described as one of the favorites of Oscar Awards raise the question of whether Cannes committee will adopt a different strategy on Netflix next year. As per the new proposal on the agenda, if a Netflix movie wins an award in Cannes, it will be required to be shown at movie theatres in France (Şahingöz, 2019).

After the efforts and initiatives at Cannes Festival, Netflix is insisted on showing their films on movie theatres and in their own platform at the same time. It tries to break the monopoly of online showing after movie theatre showing which prevails for a long time. These efforts of Netflix on movie production and distribution which is far from commercial concerns and close to art cinema are recognized as the efforts of gaining prestige in the eye of Hollywood and joining Oscar race. Netflix is also assertive and established itself in television and series. It disturbs its competitors in Emmy Awards with 112 nominations it had. Despite not being as prestigious as in television, the company aims to be a candidate to Oscar and win a prize (Vena, 2018). Meanwhile, Netflix movie "Rome", won three Oscars including the Best Director, Best Foreign Film and Best Cinematography in 2019 Oscar ceremony.

Another example of Netflix's efforts to be active and effective outside the USA is the efforts of the company to produce European movies 33\% more and show them in traditional television. These initiatives and plans directly concern the European broadcasters and the actors in the same industry in the USA. Netflix and its competitors Hulu and Amazon Prime Video plan to triple their investments by spending 10 million dollars annually (Ness, 2018).

An article bearing the signature of Brogan Morris claims that Netflix does not have any feature threatening the cinema. According to Morris, change is always troublesome. The distributors have also applied various distribution strategies for years. Netflix has reached 100 million subscribers. This did not much detract the cinema viewers from the cinema. The number of viewers partially decreased in 
the USA and increased in the Europe. Netflix supports the low-budgeted projects that are not supported in Hollywood. According to the author, Netflix's popular cinema approach and perception of high-budgeted films differentiate from Hollywood's views. While studios are continuing with the common and high-yield projects without taking any risks, Netflix goes on spending big budgets on interesting and original ideas. Trying to produce and show various kinds of movies, Netflix presents an alternative to film watching at the cinema and thus results in a healthy and needed competition (Morris, 2018).

One of the highly debated demands of Netflix similar online movie and series streaming companies is the demand of showing cinema films in their own platforms shortly after their show at the movie theatres. Netflix is insisted that this period should be 4 weeks. A hot debate occurred related to this subject in February in Turkey. Turkish movie titled "Organize İşler-Sazan Sarmalı" was broadcasted in Netflix after 15 days of its release on February 1 in movie theatres. This situation is a first for the industry and led to hot debates. The columnist Cengiz Semercioğlu wrote several articles in his column at the newspaper. According to the columnist, after its show in Netflix, weekend box office return of "Organize İşler" decreased $5 \%$. This means a loss which is only $5 \%$ below its normal show. In his article, Semercioğlu claims that Digiturk, the oldest platform having the highest number of subscribers in Turkey, will be affected from the mentioned film's being shown in Netflix in a very short time after its show at movie theatres. Because Netflix directly interfered in the food chain progressing as "vision-encrypted channel-DVD-unencrypted channel". Such platforms as Netflix, Apple TV, Hulu and Prime are called as "cord cutters" in the world. These digital platforms are the greatest nightmares of channels operating via subscription system known as cabled channels (Semercioğlu, 2019).

Cannes Film Festival-Netflix debate is actually the debate of "all movies shot are cinema films?" It has made questions and debates like "Is it possible to regard a movie not shown at the cinema as a cinema film?" more visible. In this context, there are two different styles and approaches. While the USA, namely the Hollywood adopts mostly the understanding of commercial cinema, French, namely the Cannes supports more the arthouse, elite art-independent cinema. According to one approach, films should be watched at the cinema, and for the other, they can be watched anywhere. In another article on Netflix, it is emphasized that these are actually ongoing debates. What is suggested in the article is that the ones at the position of manager and decision-makers often do not care about the viewer opinion and give the viewers any right to speak (Braun, 2018:20).

In this context, it seems the market share of the online series and film platforms which take the viewer expectations into consideration, asses their opinions, provide affordable and qualified service will increase. Movie theatres will continue to survive by developing their strategies against their current competitors as well.

\section{Conclusion}

Recently, some of subjects in the field of cinema and communication studies have come into prominence than before. "Digitalization" is one of the subjects in question. Apart from development and changes of electronic devices, digitalization, which progresses in parallel with the technological developments, also performs as driving force for change and transformation taking or to take place in the society. Technological development for cinema indicates milestone with regard to style and content more than the developments on mobile phone models and internet infrastructure. The written or unwritten rules and unspoken habits which have been standardized, settled, unquestioned and taken for granted for nearly 100 years have become controversial topic

Although Netflix participated in the Cannes Film Festival in May 2017, Netflix's films were disqualified from the competition over decision not to be played any Netflix film in French cinemas, there is still ongoing debate about the issue. In many news and articles about Netflix, it has been referred to the company's situation at Cannes Film Festival and the nomination for an Oscar with "Roma" which won several. In this study, the articles published as printed or in the digital environment after the event over a 2-year period have been analyzed. The situation of the company in Cannes Film Festival and has been reported and several awards after being nominated for Oscar have been referred in various article or news regarding Netflix reported.

Numerous articles analyzed or discussed shows that there are different approaches about situation-position of Netflix. There are negative approaches, as well as positive ones. It can be said 
that there is no consensus. There are changes and developments in the field of production distribution. While there is positive progress towards the field of production, independency and creativity, there is huge discussion about where, when and how long the films will be shown. Commercial cinema is also troublesome. "Arthouse", namely "Independent Cinema", struggles for existence. In this field, there are several problems in production and distribution area. Audience and viewing pleasure constitute common ground. The competition can pave the way for More qualified movies and series. Movies should be given a chance in accordance with different viewing pleasure. The opportunity of movie experience should be provided not according to specific income groups but according to various income groups. The open-closed competition, difference of notion between Europe Cinema and Hollywood have been become the current issue again with the influence of Netflix. What digitalization brought is to question various approaches and rules as well as technological development. Difference of understanding between digital native generation $Z$ and digital immigrant generation $X$ has been getting more and more clear in some areas. Transformation of technological devices into watching displays ever increasingly give rise to questioning "A movie should be watched at the cinema" approach which is indispensable part of persons. Neither audience nor cinemas should be prominent here. Both of them should complete each other. Rapid growth of Netflix and aggressive advertisement and distribution policy have drawn negative reaction of many film production companies and movie theater owners in the Europe, particularly in America. 130 million subscribers in 190 countries that make Netflix leader in the field prompt rival film companies and television networks to take precautions.

In addition, regardless spoken or unspoken, the challenges of the industry constantly become a matter of debate after Netflix-Cannes Film Festival polemic taking place in 2017. There have been panel and forums in written and digital environment for 2 years thanks to film websites, articles in many countries in the world. In the study, some of them have been chosen and scrutinized. Due to the fact that the topic is ongoing and hot and at the same time topic itself is online and digital, most of the references are the internet references. Francesco Casetti's opinions and study, prominent and wellrespected academician in the field, have been taken as reference to contribute the study and developments. Casetti scrutinizes the change and transformation of film production, distribution and viewing environment with 7 keywords. As analyzing the change and transformation over the audiences and their preferences and emphasizing that some habits will eventually change, he claims the cinema will become adjusted to the process.

Within the scope of the study, it has become clear that the ones taken as reference discuss the current problems. Rather than cause the problems, Netflix, as an important actor, makes the problems in film industry evident and makes efforts to have its own position. Netflix paved the way for questioning of centenarian cinema and 70-year television approach.

In reality, the cinema is a technological product and its development arose from technological advances. Social, economic and psychological changes and issues resulted from technology directly have an effect on cinema, presence of the branch of art mostly depends on the audience and more audience if possible.

Netflix and most of its rival companies have the USA and Hollywood origin. Within this framework, cinema is indispensable source of income for the individuals who buy and hire its product in the USA. Independent cinema, that is, arthouse cinema, try to have its own position in such atmosphere where billions of dollars box office gross takes place. Some of movie makers who could not take enough financial support from Hollywood are in cooperation with Netflix. As a result, the influence and power of movie theaters will decrease as well as that creative and qualified movies will be produced and independent cinema will reach more advantageous position than it used to.

\section{References}

[1] Braun, M. (2018) Netflix gebingewatched, geweint, Trailer, 1, 20.

[2] Casetti, F. (2015). The Lumiere Galaxy -7 Key Words for the Cinema to Come. New York: Columbia University Press.

[3] Colin, R. (2017, May 24). Netflix boss Ted Sarandos on Cannes controversy: 'Unlike us, the studios have no appetite for risk, Retrieved from http://www.telegraph.co.uk/ondemand/0/netflix-boss-ted-sarandos-cannes-controversy-future-film-studios/. 
[4] İzleyiciye dilediğini seçme özgürlüğü verildiğinde TV izleme alışkanlıkları alt üst oluyor (2017, May 23) Retrieved from https://media.netflix.com/tr/press-releases/four-years-after-house-ofcards-netflix-members-elect-their-owntv-schedule.

[5] Morris, B. (2017, June 5). In Spite of the Cannes Controversy, Netflix Isn't Committing Cinematic Heresy, Retrieved from https://www.pastemagazine.com/articles/2017/06/in-spiteof-the-cannes-controversy-netflix-isnt-co.html

[6] Ness, S. (2018, December 3). Netflix to produce More European Content, Retrieved from https://marketrealist.com/2018/12/netflix-to-produce-more-european-content.

[7] Taş Öz, P. (2012). Pelikülden Dijitale Sinemada Seyir Kültürü ve Seyircinin Değişen Konumu. TOJDAC, 2 (2), 72.

[8] Rolf, A. (2017). Seiner Zeit voruas, TV Spielfilm, 9-15 Eylül, 8.

[9] Semercioğlu, C. (2019, February, 19). Netflix'in abonesi kaç kişiyi etkiledi? Retrieved from http://www.hurriyet.com.tr/yazarlar/cengiz-semercioglu/netflixin-abonesi-kac-giseyi-ne-kadaretkiledi-41121658.

[10] Şahinöz, S. (2019, February 2). Netflix filmlerinin cannes film festivali'nde yarişmasi için festival yönetmenliğinde değişikliğe gidilebilir, Retrieved from https://www.filmloverss.com/netflix-filmlerinin-cannes-film-festivalinde-yarismasi-icinfestival-yonetmenliginde-degisiklige-gidilebilir/.

[11] Şakiroğlu, M., Akyol C.P., (2018) Çocukları Sanal Dünyada(n) Koruma Kılavuzu, İstanbul: Hayykitap.

[12] Şalom, J. (2017). Sinema Salonlarının Sonu Mu? Altyazı, 174, 85-88

[13] Vena, D. (2018, December 2) Netflix Makes an Unprecedented Move in Pursuit of Oscar Gold Retrieved from https://finance.yahoo.com/news/netflix-makes-unprecedented-move-pursuit150500612.html

[14] Yeni Mecra Yeni Sorunlar (2017), Hayal Perdesi, 59,43.

[15] Zakarin, J. (2017, May 19). Netflix Isn't Killing Movies, Hollywood Studios and Theaters Are, Retrieved from https://www.inverse.com/article/31865-cannes-netflix-booing-okja-studioshurting-movies. 